\title{
Ecological impact of coal mines on lichens: A case study at Moghla coal mines Kalakote (Rajouri), J\&K
}

\author{
Sangeeta Charak ${ }^{1}$, Mukhtar A. Sheikh ${ }^{1}$, Anil K. Raina ${ }^{1 *}$ and D. K. Upreti ${ }^{2}$ \\ ${ }^{1}$ Department of Environmental Sciences, University of Jammu, Jammu-180006, INDIA \\ ${ }^{2}$ Lichenology Lab., National Botanical Research Institute, Lucknow-226001, INDIA \\ *Corresponding author. E-mail: anilkraina@yahoo.com
}

\begin{abstract}
The data on the frequency, density and abundance of the lichens growing around the Moghla Coal mines, Kalakote has been recorded and compared with lichens growing in a forest area away from the coal mines to work out effect of coal mines on the diversity and distribution of lichens. The data revealed that pollutants released by the open coal mining activities not only effected qualitative distribution but also have effect on the quantitative parameters. Over all 10 species of lichens belonging to 9 genera and 6 families have been recorded from the vicinity of coal mines as compared to 15 species, belonging to 9 genera and 7 families, recorded from the forest area.
\end{abstract}

Keywords: Lichens, Ecological impact, Kalakote coal mines, J\&K

\section{INTRODUCTION}

Lichens have sensitivity, both physiological and ecological, to pollutants and therefore have been employed almost exclusively to monitor the extent or spread of air pollution particularly $\mathrm{SO}_{2}$ (Gries et al., 1997). Lichen diversity is an excellent indicator of pollution by phytotoxic gaseous substances and respond relatively fast to a deterioration in air quality. Due to lack of cuticle, lichen absorbs both gases and dissolved substances through their surface. Reduction in air pollution has been reported to result in recovery of lichen abundance (Showman, 1990; Kirschbaum et al., 1996). The pollutants such as $\mathrm{SO}_{2}$ and $\mathrm{O}_{3}$ (ozone) which are absorbed by the lichens leads to loss of chlorophyll, reduced rate of photosynthesis and eventual plasmolysis of algal cells (Rao and de Blanc, 1965). Murphy et al. (1999) used lichen abundance to indicate whether a rural, coal burning, electrical generating station in the northern USA has measurable impacts on the surrounding forest.

In the present study frequency, density and abundance of the lichens has been recorded near the Moghla coal mines, Kalakote (latitude $33^{\circ} 10^{`} \mathrm{~N}$, longitude $74^{\circ} 45^{`} \mathrm{E}$ and altitude $600 \mathrm{~m}$ above m.s.l) in Rajouri district of J\&K state, to know the effect of the coal mines on the qualitative and quantitative distribution of lichen vegetation present in the surrounding areas.

\section{MATERIALS AND METHODS}

To analyse the impact of coal mines on lichens, collection of the lichens were made from base to chest height of the tree trunks of the selected trees from two different location: Site I, in the vicinity of coal mines $(100 \mathrm{~m})$ and Site II, Treru forest area located $6 \mathrm{~km}$ away from the coal mines. A quadrat of $25 \mathrm{x} 25 \mathrm{~cm}$ size was used for recording the data on frequency, density and abundance of lichens growing on the selected trees. However, the collection of lichen samples has been made from all the available substratum in the study area. The specimens were identified by the recent literature of Awasthi (1988, 1991, and 2000), Divakar (2001) and Nayaka (2004). Thin layer chromatography was performed by the methods of Culberson (1972) and Walker and James (1980) for lichen substances. The data was recorded from the dominant tree species- Mallotus phillippensis, Punica granatum, Carissa opaca and Alnus incongruens at both the sites.

\section{RESULTS AND DISCUSSION}

The lichen community present at the Treru Forest area and Moghla coal mine area form two types of assemblage of lichen species i. e. either growing on tree trunks (corticolus) or on the rocks (saxicolous). The area is represented by 2 growth forms of lichens - crustose and foliose. At Site- I, only 10 species belonging to 9 genera and 6 families have been recorded while as 15 species belonging to 9 genera and 7 families have been observed to grow at Site-II (Table 1and 2). This clearly indicated that the coal mines have effected the qualitative distribution of the lichens in the area under report, same was observed by Murphy et al. (1999) in England. 
Perusal of the table 3 also revealed that all the quantitative parameters i.e. frequency, density and abundance of the species, have been effected by the coal mine pollution. All these parameters have been recorded to have lower values at Site I (coal mines area) than that of the Site II (forest area). Smith et al. (1993) also reported that by estimating lichen cover, the lichens can be used for bioindicator studies.

The analysis of the recorded data further revealed that seven lichen species grow at both of the sites (Table 4) and show variations in their quantitative parameters. These species may be recognized as pollution tolerant species and can be further exploited for recording the effects of coal mines pollutants on the growth and development of lichens.

Thus, results of present study indicated that various pollutant gases $\left(\mathrm{SO}_{2}, \mathrm{H}_{2} \mathrm{~S}\right.$ etc.) and particulate matter (SPM) produced at Moghla coal mines, Kalakote affected the diversity and distribution of the lichen vegetation both qualitatively and quantitatively.

Table 1. Lichen species collected from Site I (coal mines area).

\begin{tabular}{llcc}
\hline Lichen taxa & Family & Substratum & Growth form \\
\hline Bacidia arnoldiana Korber & Bacidiaceae & $\mathrm{R}$ & $\mathrm{Cr}$ \\
Graphis sp.II & Graphidaceae & $\mathrm{B}$ & $\mathrm{Cr}$ \\
Hyperphyscia adglutinata (Florke) Mayrh. \& Poelt & Physciaceae & $\mathrm{B}$ & $\mathrm{Fo}$ \\
Lecanora perplexa Brodo. & Lecanoraceae & $\mathrm{B}$ & $\mathrm{Cr}$ \\
Lepraria lobificans Nyl. & Lichenes imperfecti & $\mathrm{B}$ & $\mathrm{Cr}$ \\
Lepraria sp.I & Lichenes imperfecti & $\mathrm{R}$ & $\mathrm{Cr}$ \\
Pyxine subcinerea Stirton & Physciaceae & $\mathrm{B}$ & $\mathrm{Fo}$ \\
Phaeophyscia orbicularis(Necker) Moberg & Physciaceae & $\mathrm{B}$ & $\mathrm{Fo}$ \\
Physcia sp. & Physciaceae & $\mathrm{B}$ & $\mathrm{Fo}$ \\
Verrucaria coerulea (Ram) DC.in Lam. \& DC & Verrucariaceae & $\mathrm{R}$ & $\mathrm{Cr}$ \\
\hline
\end{tabular}

Table 2. Lichen species collected from Site II (Forest area).

\begin{tabular}{llcc}
\hline Lichen taxa & Family & Substratum & Growth form \\
\hline Bacidia incongruens (Striton) Zahlbr. & Bacidiaceae & $\mathrm{R}$ & $\mathrm{Cr}$ \\
Caloplaca malaensis (Rasanen) Awasthi & Teloschistaceae & $\mathrm{B}$ & $\mathrm{Cr}$ \\
Caloplaca subsolata (Nyl.) ) Zahlbr. & Teloschistaceae & $\mathrm{R}$ & $\mathrm{Cr}$ \\
Graphis sp.I & Graphidaceae & $\mathrm{B}$ & $\mathrm{Cr}$ \\
Graphis sp.II & Graphidaceae & $\mathrm{B}$ & $\mathrm{Cr}$ \\
Hyperphyscia adglutinata (Florke) Mayrh. \& Poelt & Physciaceae & $\mathrm{B}$ & $\mathrm{Fo}$ \\
Lecanora perplexa Brodo. & Lecanoraceae & $\mathrm{B}$ & $\mathrm{Cr}$ \\
Lecanora sp. I & Lecanoraceae & $\mathrm{B}$ & $\mathrm{Cr}$ \\
Lecanora sp. II & Lecanoraceae & $\mathrm{B}$ & $\mathrm{Cr}$ \\
Lepraria lobificans Nyl. & Lichenes imperfecti & $\mathrm{B}$ & $\mathrm{Cr}$ \\
Lepraria sp.I & Lichenes imperfecti & $\mathrm{R}$ & $\mathrm{Cr}$ \\
Lepraria sp.II & Lichenes imperfecti & $\mathrm{B}$ & $\mathrm{Cr}$ \\
Parmotrema praesorediosum (Nyl.) Hale & Parmeliaceae & $\mathrm{B}$ & $\mathrm{Fo}$ \\
Pyxine subcinerea Stirton & Physciaceae & $\mathrm{B}$ & Fo \\
Phaeophyscia orbicularis(Necker) Moberg & Physciaceae & $\mathrm{B}$ & Fo \\
\hline
\end{tabular}


Table 3. Showing frequency, density and abundance of lichens at Site I and Site II.

\begin{tabular}{|c|c|c|c|c|c|c|c|}
\hline \multirow[t]{2}{*}{ Lichen taxa } & \multirow[t]{2}{*}{ Host } & \multicolumn{3}{|c|}{ Site-I } & \multicolumn{3}{|c|}{ Site-II } \\
\hline & & $\begin{array}{c}\text { Freq. } \\
(\%)\end{array}$ & $\begin{array}{c}\text { Dens./ } \\
625 \mathrm{~cm} 2\end{array}$ & Abun. & $\begin{array}{c}\text { Freq. } \\
(\%)\end{array}$ & $\begin{array}{c}\text { Dens./ } \\
625 \mathrm{~cm} 2\end{array}$ & Abun. \\
\hline Graphis sp.II & Punica granatum & 1.0 & 20.1 & 3.0 & 1.2 & 40.0 & 3.5 \\
\hline Hyperphyscia adglutinata & Alnus incongruens & 50.0 & 0.9 & 2.6 & 63.3 & 1.6 & 3.0 \\
\hline Hyperphyscia adglutinata & Mallotus philippensis & 40.0 & 1.0 & 2.7 & 42.8 & 1.7 & 5.0 \\
\hline Lecanora perplexa & Punica granatum & 1.2 & 20.0 & 4.2 & 1.5 & 40.0 & 5.7 \\
\hline Lecanora perplexa & Carissa opaca & 10.0 & 0.2 & 1.0 & 18.2 & 0.27 & 1.5 \\
\hline Phaeophyscia orbicularis & Mallotus philippensis & 40.0 & 1.0 & 2.0 & 57.1 & 3.2 & 5.7 \\
\hline Phaeophyscia orbicularis & Alnus incongruens & 45.5 & 1.0 & 2.7 & 50.0 & 1.6 & 3.3 \\
\hline Pyxine subcinerea & Carissa opaca & 10.0 & 0.2 & 1.0 & 27.2 & 0.9 & 3.3 \\
\hline
\end{tabular}

Table 4. Lichen species common at Site I and Site II.

\begin{tabular}{lllc}
\hline Lichen taxa & Family & $\begin{array}{c}\text { Substratum } \\
\text { Growth } \\
\text { form }\end{array}$ \\
\hline Graphis sp.II & Graphidaceae & $\mathrm{B}$ & $\mathrm{Cr}$ \\
Hyperphyscia adglutinata (Florke) Mayrh. \& Poelt & Physciaceae & $\mathrm{B}$ & $\mathrm{Fo}$ \\
Lecanora perplexa Brodo. & Lecanoraceae & $\mathrm{B}$ & $\mathrm{Cr}$ \\
Lepraria lobificans Nyl. & Lichenes imperfecti & $\mathrm{B}$ & $\mathrm{Cr}$ \\
Lepraria sp. I & Lichenes imperfecti & $\mathrm{R}$ & $\mathrm{Cr}$ \\
Pyxine subcinerea Stirton & Physciaceae & $\mathrm{B}$ & $\mathrm{Fo}$ \\
Phaeophyscia orbicularis (Necker) Moberg & Physciaceae & $\mathrm{B}$ & Fo \\
\hline
\end{tabular}

\section{REFERENCES}

Awasthi, D.D. (1988). A key to the Macrolichens of India and Nepal. J. Hattori. Bot.Lab.65: 207-302.

Awasthi, D.D. (1991). A key to the Mircolichens of India, Nepal and Sri Lanka. Biblioth. Lichenolog.40:1-337.

Awasthi, D.D. (2000). Lichenology in Indian Subcontinent. Bishen Singh Mahendra Pal Singh, Dehradun.

Culberson (1972). Improved conditions and new data for the identification of lichen products by a standardized thin layer chromatographic method. Journal of chromatography, 72:113125.

Divakar, P.K. (2001). Revisionary studies on the lichen genus Parmelia Sensu Lato in India. Ph. D. Thesis, Lucknow University Lucknow, India.

Gries, C., Sanz, M.J., Romagni, J.G., Goldsmith, S., Kuhn, U., Kesselmeier, J and Nash, T.H., III. (1997). The uptake of gaseous sulfur dioxide by non-gelatinous lichens. New Phytologist, 35:595-602.

Kirschbaum, U., Marx, A. and Schiek, J.E. (1996). Assesment of air pollution in Giessen and Wetzlar on the basis of epiphytic lichen growth. Journal of Applied Botany, 70:7896.

Nayaka, S. (2004). Revisionary studies on lichen genus Lecanora Sensu Lato in India. Ph.D. Thesis, Dr. R.M.L.Avadh University Faizabad, India.

Murphy, K.J., Alpert, P. and Cosentino, D. (1999). Local impact of a rural coal burning generating station on lichen abundance in a New England. Environmental pollution, 105:349-354.

Rao and de Blanc (1965). Effect of $\mathrm{SO}_{2}$ on the lichen algae, with special references to chlorophyll. Bryologist 69(1):69-74.

Showman, R.E.(1990). Lichen recolonization in the upper Ohio River Valley. Bryologist, 93: 427-428.

Smith, C., Geiser, L., Gough, L., Mc Cune, B., Ryan, B. and Showman, R. (1993). Species and communities. In: L.S. Huckaby (Ed.), Lichens as Bioindicators of air quality (pp. 41-66).Chicago, Fort Collins.

Walker, F.J. and James, P.W. (1980). A revised guide to the microchemical technique for the identification of lichen products. Bull. Brit. Lich. Soc. 46: 13-29. 